\title{
Holocene land-use evolution and associated soil erosion in the French Prealps inferred from Lake Paladru sediments and archaeological evidences.
}

Simonneau $\mathrm{A}^{\mathrm{a} *}$, Doyen $\mathrm{E}^{\mathrm{b}}$, Chapron $\mathrm{E}^{\mathrm{a}}$, Millet $\mathrm{L}^{\mathrm{b}}$, Vannière $\mathrm{B}^{\mathrm{b}}$, Di Giovanni $\mathrm{C}^{\mathrm{a}}$, Bossard $\mathrm{N}^{\mathrm{a}}$, Tachikawa $\mathrm{K}^{\mathrm{c}}$, Bard $\mathrm{E}^{\mathrm{c}}$, Albéric $\mathrm{P}^{\mathrm{a}}$, Desmet $\mathrm{M}^{\mathrm{d}}$, Roux $\mathrm{G}^{\mathrm{e}}$, Lajeunesse $\mathrm{P}^{\mathrm{f}}$, Berger $\mathrm{JF}^{\mathrm{g}}$, Arnaud $\mathrm{F}^{\mathrm{h}}$.

*corresponding author: anaelle.simonneau@ univ-orleans.fr, +33238494665

Others : elise.doyen@ univ-fcomte.fr, emmanuel.chapron@univ-orleans.fr, laurent.millet@univ-fcomte.fr, boris.vanniere@univ-fcomte.fr, Christian.Di-Giovanni@univorleans.fr, nicolas.bossard@univ-orleans.fr, kazuyo@ cerege.fr, bard@ cerege.fr, patrick.alberic@univ-orleans.fr, marc.desmet@univ-tours.fr, Gwenaelle.ROUX@entpe.fr, Patrick.Lajeunesse@ggr.ulaval.ca, Jean-Francois.Berger@univ-lyon2.fr, fabien.arnaud@univ-savoie.fr

a ISTO, UMR 7327 CNRS ; Univ. Orléans ; BRGM, 1A rue de la Férollerie, 45071 Orléans Cedex 2, France.

${ }^{\mathrm{b}}$ Laboratoire de Chrono-Environnement, UMR 6249 CNRS, UFR des Sciences et Techniques, 16 route de Gray, 25030 Besançon, France.

${ }^{c}$ CEREGE, Université Aix-Marseille, CNRS, IRD, Collège de France, Technopole de l’Arbois, BP80, 13545 Aix en Provence, France.

${ }^{\text {d}}$ E.A. 6293 GéHCO, GéoHydrosystème COntinentaux, Université F. Rabelais de Tours, Département Géosciences-environnement, Faculté des Sciences et Techniques, Parc de Grandmont, 37200 Tours, France.

${ }^{\mathrm{e}}$ Université Lyon 1, UMR 5023 Ecologie des Hydrosystèmes Naturels et Anthropisés, ENTPE, CNRS, 3, Rue Maurice Audin, 69518 Vaulx-en-Velin, France.

${ }^{\mathrm{f}}$ Centre d'étude nordiques et Département de Géographie, Univ. Laval, Québec, QC, Canada. 
${ }^{g}$ UMR 5600 EVS du CNRS, Université Lyon 2, Faculté Ghhat, 5 Avenue Pierre MendèsFrance, 69676 BRON Cedex, France.

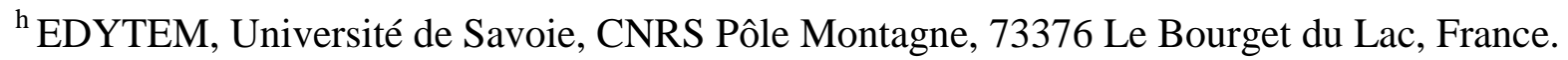




\begin{abstract}
A source-to-sink multi-proxy approach has been performed within Lake Paladru (492 m a.s.l., French Prealps) catchment and a six-meter long sediment sequence retrieved from the central lacustrine basin. The combination of minerogenic signal, specific organic markers of autochthonous and allochthonous supply and archaeological data allows the reconstruction of a continuous record of past human disturbances. Over the last 10000 years, the lacustrine sedimentation was dominated by autochthonous carbonates and the watershed was mostly forest-covered. However, seven phases of higher accumulation rate, soil erosion, algal productivity and landscape disturbances have been identified and dated from 8400-7900, 6000-4800, 4500-3200, 2700-2050 cal BP as well as AD350-850, AD1250-1850 and after AD1970. Before $5200 \mathrm{cal} \mathrm{BP}$, soil erosion is interpreted as resulting from climatic deterioration phases toward cooler and wetter conditions. During the Mid-Late Holocene period, erosion fluxes and landscape disturbances are always associated with prehistorical and historical human activities and amplified by climatic oscillations. Such changes in human land-used led to increasing minerogenic supply and nutrients loading that affected lacustrine trophic levels, especially during the last 1600 years. In addition, organic and molecular markers document previously unknown human settlements around Lake Paladru during the Bronze and the Iron Ages.
\end{abstract}

\title{
Keywords
}

French Prealps; Holocene; lake sediment; organic geochemistry; land-use; soil erosion 


\section{Introduction}

To understand potential future relationships between environment, human societies and global change, it is essential to identify the past interactions between human land-use and climate fluctuations (Hurtt et al., 2006). Bosco et al. (2009) have also highlighted a probable future increase of soil erosion in the Alps. Soil erosion can result from climatic and/or anthropogenic impacts since it is mainly controlled by changes of the vegetation cover (Le Bissonnais et al., 2001). The discrimination between climate and human-induced environmental changes remains however complex and needs to be addressed by accurate proxies supported by historical or archaeological evidences. Numerous studies have demonstrated that natural deposits, as lacustrine sedimentary sequences, can provide continuous high-resolution records of climate changes and anthropogenic environmental disturbances (Dearing, 2006, Jacob et al., 2008, Ariztegui et al., 2010).

Climate or human imprints are classically highlighted in lacustrine sediments by chemical analysis (Guiguet-Covex et al., 2011) or microfossils identification (Tinner et al., 2003), but can also be detected by organic geochemistry (Noël et al., 2001) and molecular markers (Jacob et al., 2008). Lake Paladru has been investigated by numerous subaquatic archaeological surveys along littoral environments (Colardelle and Verdel, 1993; Borel et al., 1994; Brochier et al., 2007) and is therefore particularly suitable to investigate human/climate interactions. These studies have clearly identified three phases of lake-dwellings on the littoral environments of Lake Paladru, during the Late Neolithic period, the Middle Age and the Modern times and suggested possible others occupation phases during the Iron Age and the Roman period.

In this paper, we studied a Holocene lacustrine sequence retrieved from the central basin of this glacial lake together with soils and fluvial sediments from the related watershed, in order to track the impact of both climate and human activities on the environment. The present study combines physical and chemical analysis with geochemical and petrographic characterization of the organic matter. Continuous measurements are used to describe and identify the sedimentary units of the sequence whereas the punctual organic geochemistry analyses attempt (i) to qualify and quantify the allochthonous from the autochthonous compounds with specific attention on the soil and higher-plants debris supply and (ii) to detect specific agricultural practices within the watershed of the lake. Confronting continuous sedimentological records of minerogenic supply, past upper vegetation disturbance, soil 
erosion and molecular markers with historical and archaeological evidences, we finally attempted to quantify the consequences of Holocene human-induced disturbances in this part of the Alpine foreland.

\section{Materials and methods}

\subsection{Sampling site}

Lake Paladru $\left(45^{\circ} 27^{\prime} \mathrm{N}-5^{\circ} 32^{\prime} \mathrm{E}\right)$ is located in the French Prealps at $492 \mathrm{~m}$ a.s.l (Figure 1). It is a small basin of glacial origin $\left(3.73 \mathrm{~km}^{2}, 5 \mathrm{~km}\right.$ long, $0.7 \mathrm{~km}$ wide, $36 \mathrm{~m}$ deep). The catchment area of $55 \mathrm{~km}^{2}$ is characterized by hilly slopes formed by the Miocene molasses of the alpine belt and by glacial or fluvial deposits from the Würm period covered by modern alluvial deposits (Bravard et al., 1970). The Surand and the Courbon Rivers are the two tributaries flowing into Lake Paladru, on its western and northern edges, respectively. South of the lake, the Fure River constitutes the outlet (Figure 1). Numerous archaeological sites have been identified by subaquatic investigations in this lake. They are dated from the Late Neolithic period (2750-2730 BC, Bocquet and Noël, 1995; Colardelle and Verdel, 1993) to the Medieval times (AD1006-1032, Colardelle and Verdel, 1993; Figure 1). According to Brochier et al., (2007), each abrupt end of these lake-dwellings can be associated with rapid rise in the water lake-level.

\section{Figure 1}

In 2008, the sedimentary infill of the lake was imaged by high-resolution seismic profiling with a subbottom profiler of $12 \mathrm{kHz}$ used from an inflatable boat and coupled with GPS navigation (Figure 1). $26 \mathrm{~km}$ of profiles were realized and used to select a suitable location for the coring site PAL09 $\left(45^{\circ} 27.478^{\prime} \mathrm{N}-5^{\circ} 32.348^{\prime} \mathrm{E}\right.$, Figures 1$)$ in the central basin of the lake (36m deep). As shown in Figure 1, this core (12m-long) was retrieved in November 2009 with an UWITEC coring device operated from a platform, in area free from mass wasting deposits (MWD) producing chaotic to transparent lense-shaped bodies. 
In November 2009, 23 carbonated pedological profiles, rich in carbonated gravels, and 3 river beds samples were collected at different altitudes and under different vegetation covers within the watershed of Lake Paladru (Figure 1). They are representative of the forested $\left(11 \mathrm{~km}^{2}\right)$, grassy $\left(5 \mathrm{~km}^{2}\right)$ and cultivated areas $\left(35 \mathrm{~km}^{2}\right)$. Three types of soils were identified: (i) well developed Stagnosol or fluvic-Stagnosol in humid pastures and swamp areas, characterized by silty to sandy layers marked by stagnic colour pattern above $50 \mathrm{~cm}$ deep; (ii) Colluvic Regosols downward the slopes, constituted of clayey to silty layers and resulting from the accumulation of material and (iii) well developed (50 to $120 \mathrm{~cm}$ thick) calcaric to hypereutric Cambisols throughout the rest of the watershed under forest, scrub or cultivated areas.

\subsection{Age-depth model}

The age-depth model of core PAL09 was established based on radiometric markers $\left({ }^{210} \mathrm{~Pb},{ }^{137} \mathrm{Cs}\right)$ measured every five millimetres for the 16 first upper centimetres and on 18 AMS ${ }^{14} \mathrm{C}$ radiocarbon dates performed at the Radiocarbon Laboratory in Poznan and at the Laboratoire de Mesure du Carbone 14 in Gif-sur-Yvette (Table 1, Figure 2B) on terrestrial vegetal remains sampled within the six upper meters. Calibrated ages were computed using the calibration curve of Intcal09 (Reimer et al., 2009) and the resulting age-depth model was interpolated by a cubic spline curve using the "clam" model developed by Blaauw (2010).

\section{Table 1}

\section{Figure 2}

\subsection{Mineral and organic signals}

Non-destructive laboratory descriptions of core PAL09 were supported by physical analyses of the magnetic susceptibility (MS, Figure 2A) acquired at each centimetre using a Geotek Multi Sensor Core Logger System and high-resolution elemental analyses performed with the X-ray fluorescence core scanner (ITRAX, Cox Analytical Systems, Croudace et al., 2006). The relative abundance of elements, such as $\mathrm{Ti}$, was measured each $5 \mathrm{~mm}$ using a chromium tube as the X-ray source at $30 \mathrm{kV}$ and $12 \mathrm{~mA}$, with $15 \mathrm{~s}$ of counting time. A total of 70 samples from the first six meters of core PAL09 and 34 samples from soils and river beds 
were selected for destructive geochemical analyses. Bulk inorganic carbon contents were measured with a LECO-CNS-2000 (Figure 2A, Weliky et al., 1983). Bulk geochemical study of the organic matter was obtained by Rock-Eval pyrolysis to characterize the organic content of natural samples by thermal cracking. The Total Organic Carbon (TOC) and the Hydrogen Index (HI) are the two main parameters used to characterize soil organic matter (Di-Giovanni et al., 1998; Sebag et al. 2006) or to identify the organic matter origin in lacustrine environments (Talbot and Livingstone, 1989). The TOC represents the amount of organic carbon in samples (\%) and the S2 (or the HI, HI=S2/TOC in $\mathrm{mgHC}^{-1}{ }^{-1} \mathrm{TOC}$ ) corresponds to the chemical quality of the organic compounds. Its decrease highlights the oxidation of the organic matter in the sediment or a contribution of terrestrial material (Ramanampisoa and Disnar, 1994). Quantitative organic petrography was done on the same set of samples. It consists of the optical identification and quantification of the organic constituents present in a constant volume of sediment $\left(1 \mathrm{~cm}^{3}\right)$ or in one gram of soil, after elimination of carbonate and silicate phases by hydrochloric and hydrofluoric treatment (Graz et al., 2010). Components are characterized by their optical properties (colour and reflectance), their forms (amorphous or figurative) and their origins (algal, phytoclastic or fossil, Tyson, 1995). In addition, 40 samples from core PAL09 were selected for lipid analyses. Following Jacob et al. (2008), they were ultrasonically extracted using a mixture of dichloromethane: isopropanol $(2: 1 \mathrm{v} / \mathrm{v})$ and separated into neutral, acidic and polar compounds on aminopropyl-bounded silica. The concentrations of specific molecular markers such as pentacyclic triterpene methyl ethers (PTMEs) were estimated by gas chromatography-mass spectrometry. Jacob et al. (2008 and 2009) demonstrated that the sedimentary miliacin was the only PTME specific of the broomcorn millet and that its detection in lacustrine sediments by gas chromatography indicated that this PTME was produced in significant amount in the catchment. Since the first occurrence of miliacin was dated from 3700 cal BP in Lake Le Bourget lacustrine sediments (Jacob et al., 2008), we focused our analyses of Lake Paladru sediments on the time-interval 4500-2000 cal BP, in order to document if such practice was regional and synchronous.

\section{Results}

\subsection{Lake Paladru sediment infill and chronology}

The substratum morphology of Lake Paladru has not been imaged by the seismic profiles and suggests that the sediment infill reaches more than 40 meters (Figure 1). The lake 
is composed of one main 36-m deep subbasin. In the central part, the rare windows of acoustic penetration show a well stratified basin infill, characterized by parallel highamplitude reflections. At the coring site, four seismic units (SU) have been identified (Figure 1). From the bottom to the top, SU1 is defined by high-amplitude and high frequency reflections, SU2 by lower-amplitude and lower frequency reflections, SU3 by an acoustically transparent unit interrupted by only one continuous reflection and SU4 by high-amplitude and low frequency reflections.

For the Holocene age-depth model of PAL09, two dates have been rejected (Figure 2B, Table 1) for being too old and potentially reworked. The Holocene period thus covered the 445 upper centimetres (Figure 2B). Modern age-depth model at site PAL09 is based on two distinct peaks in ${ }^{137} \mathrm{Cs}$ at 8.5 and $4 \mathrm{~cm}$ below lake floor (Figure $2 \mathrm{~B}$ ), interpreted as corresponding to nuclear-weapons testing at AD1963 (Beck et al., 1990) and the Chernobyl accident at AD1986 (Anspaugh et al, 1988), respectively. This is supported by dates estimated using the ${ }^{210} \mathrm{~Pb}$ constant-flux, constant-supply model (Appleby and Oldfield, 1978).

MS, carbonate contents and TOC led to define five sedimentary units (U1 to U5, from base to top, respectively, Figure 2A). U1 is defined by the highest MS values of the sequence $\left(20.10^{-5} \mathrm{SI}\right)$ and by the lowest calcium carbonate and organic contents $(20 \%$ and $<0.5 \%$, respectively). The transition with the second unit U2 occurred around $13720 \pm 140$ cal BP (Figure 2B) and matches the transition between SU1 and SU2. U2 is characterized by fluctuations of MS (from 17 to $3.10^{-5} \mathrm{SI}$ ) values and higher calcium carbonates and organic amount than in $\mathrm{U} 1(>50 \%, 0.5<\mathrm{TOC}<1 \%$, respectively). The $\mathrm{U} 2$ mean accumulation rate is equal to $0.3 \mathrm{~mm} \cdot \mathrm{a}^{-1}$. Around $7360 \pm 140 \mathrm{cal} \mathrm{BP}$, the sedimentation shifted to unit U3 defined by low and stable values of MS (around $1.10^{-5} \mathrm{SI}$ ), high carbonates content $(>50 \%)$, increasing values of TOC (from 0.8 to $1.2 \%$ ) and a mean accumulation rate equals to $0.3 \mathrm{~mm} \cdot \mathrm{a}^{-1}$. One atypical light-coloured thin layer with a sharp base, dated from $5190 \pm 50 \mathrm{cal} \mathrm{BP}$, is identified by eye-description and matches the acoustic reflection observed through SU3 on seismic profiles. Around $2370 \pm 120 \mathrm{cal} \mathrm{BP}$, the accumulation rate increased to $0.7 \mathrm{~mm}^{\mathrm{yr}}{ }^{-1}$ reflecting a change in the sedimentary infill that corresponds to the transition towards $\mathrm{U} 4$ which is characterized by increasing values of MS $\left(>5.10^{-5} \mathrm{SI}\right)$ but constant carbonate and organic contents (50\% and $1.2 \%$, respectively). Higher MS values through U4 $\left(>6.10^{-5} \mathrm{SI}\right)$ highlight some dark-coloured thin layers, whereas lower values $\left(<5.10^{-5} \mathrm{SI}\right)$ correspond to light- 
coloured carbonate rich layers. Finally, U5 is characterized by lower values of MS $\left(2.10^{-5} \mathrm{SI}\right)$, lower carbonate contents (40\%) but the highest values of TOC (1.7\%). Even if this last sedimentary unit is too thin to be recognized on seismic profiles, its onset in AD1970 \pm 3 suggests that U5 marked an important modern modification in the environment since the accumulation rate reached $1.8 \mathrm{~mm} \cdot \mathrm{a}^{-1}$.

\subsection{Specific organic signals of soils, river-beds and lacustrine sediments}

Soils and river beds samples (dark squares and grey triangles, respectively, Figure 3A) are characterized by various TOC contents (from 0.04 to $12.14 \%$ ) and HI values essentially inferior to $300 \mathrm{mgHC} \cdot \mathrm{g}^{-1} \mathrm{TOC}$ (from 337 to $118 \mathrm{mgHC} \cdot \mathrm{g}^{-1} \mathrm{TOC}$ ) typical of the terrestrial pole described by Millet et al. (2007). Two groups of organic components are identified in soils (whatever the layer) and river-beds (Figure 3B): (i) non-pollen microfossils with colloidal red amorphous particles defined by diffuse external limits and without internal structures (rAP), ligno-cellulosic fragments (LCF) and opaque particles without high reflectance and (ii) pollen microfossils represented by spores and pollens. The rAP are similar to the ones observed in soils or lacustrine environments by Sebag et al. (2006) or Noël et al. (2001) and correlated to pedological origin. They are preferentially delivered by runoff process occurring on grassy areas whereas LCF come from runoff on forested topsoils (Graz et al., 2010). Besides, topsoil layers are always characterized by TOC superior to $2 \%$ and by the highest HI values (Figure 3A) corresponding to the preponderance of higher-plants debris (LCF) which form the litter on the surface of each topsoil (Sebag et al., 2006). This fresh organic matter is also abundant in fluvial sediments (Figure 3A), suggesting that it can be easily transported from the catchment to the lake by rivers.

\section{Figure 3}

Lacustrine sediments (Figure 3A) are defined by various TOC contents (from 0.2 to 12\%) and $\mathrm{HI}$ values fluctuating between 750 and $300 \mathrm{mgHC} \cdot \mathrm{g}^{-1} \mathrm{TOC}$ that is between the algal pole (Talbot and Livingstone, 1989) and the terrestrial one (Millet et al., 2007). It corresponds to a mixture of autochthonous and allochthonous material in the background lacustrine 
sediment. As previously presented, measurements performed in the sedimentary unit U5 are characterized by the highest organic carbon content (1.7\%) and by the highest HI values (Figure 3A). Quantitative organic petrography analyses have demonstrated that all lacustrine samples only differ from the watershed ones by the presence of grey amorphous particles (gAP, Figure 3B) corresponding to products of algal growth in the lake waters (Patience et al., 1995). Since the gAP content (Figure 4A) and HI values (Figure 4B) are correlated ( $R=0.86$, $\mathrm{p}<0.001)$, HI therefore reflects the algal contribution into Lake Paladru sediments. The abundances of rAP and LCF within the lacustrine sediment are depicted in Figures 4C and $4 \mathrm{D}$, respectively. Both particles are transported by sheet runoff processes affecting the entire surface of the catchment since slopes are below 30\% (Cerdà, 1998).

\section{Discussion: Human- or climate-induced Holocene soil erosion and upper-vegetation disturbances}

The evolution of the sedimentation accumulation rate (Figure 4E) reflects both autochthonous (Figure 4A) and allochthonous (Figures 4C and 4D) contributions from the water column and from drainage-basin, respectively. Periods of higher accumulation rates are characterized by synchronous higher phytoplankton production and enhanced soil erosion (Figure 4). Following Reynolds et al. (2000), soil organic fraction supply can promote nutrients loadings and favour algal productivity. Lakes can in addition be considered as integrative sinks both of past large scales environmental changes induced by climate and of local anthropogenic activities usually restricted to the vicinity of the villages (Bouby and Billaud, 2001). The organic and the minerogenic composition of the lacustrine sediment have been used to discuss whether soil destabilizations are caused by Holocene human land-use or climate (c.f. Noël et al., 2001; Chapron et al., 2005; Arnaud et al., 2012). Indeed, the rAP/LCF ratio (Figure 4F) corresponds to the respective contribution of less vegetated versus forested topsoil layers in the fluxes of terrestrial organic matter transported to the lake by runoff (Di Giovanni et al., 2000). However, disturbed areas affected by human land-use, such as cultivated places, are preferentially eroded (Duchaufour, 1983) and can thereby artificially and significantly increase the ratio $\mathrm{rAP} / \mathrm{LCF}$ even if the catchment is forest-covered.

Inversely, a drop in the ratio rAP/LCF can result from intensive land-used, such as ploughing, affecting deeper soil layers where the ratio $\mathrm{PAP} / \mathrm{LCF}$ is constant whatever the vegetation cover (Graz et al., 2010) and not from a reforestation. Such limits highlight the necessity to compare 
the ratio $\mathrm{rAP} / \mathrm{LCF}$ with indirect measurements, such as minerogenic supply (titanium for example, Figure 4H) which points to enhanced physical weathering of alumino-silicates within soil layers that can be due to climate or more intense land-use (Massa et al., 2012).

\section{Figure 4}

Since $13720 \pm 140$ cal BP, Lake Paladru is characterized above SU1 by a drastic drop of clastic supply (documented both by high sediment MS and Ti supply), an increase of calcium carbonate production in the water column and a rise in TOC (Figure 2A) that favoured the onset of a lacustrine drape (Figure 1). During the Early Holocene period, autochthonous carbonates and algae production dominated the sedimentation, while the MidLate Holocene is characterized since ca. $5200 \mathrm{cal}$ BP by both a progressive and irregular rise in minerogenic (MS, Ti) and organic (rAP) soil supply (Figures 2A, 4C and 4H) and a gentle decrease in upper vegetation debris inputs (LCF, Figure 4D) suggesting a drop in the forested cover. Besides, this change could match first regional human land-use (Berger et al., 2007a). The evolution of $\mathrm{rAP} / \mathrm{LCF}$ is afterwards reflecting a mainly forested watershed during all the Holocene period (Figure 4F). Seven main phases of higher accumulation rates (Figure 4E) are recorded (grey strips, Figure 4) and correspond to periods of enhanced erosion of the soil organic fraction (Figure 4C) and higher landscape disturbances (Figure 4F). They are dated from 8400-7900, 6000-4800, 4500-3200, 2700-2050 1600-1100 cal BP, AD1250-1850 and after AD1970. LCF particles show, in addition, exceptional high concentrations around 5650 and 5000 cal BP.

\subsection{0-7900 cal BP: climate-induced disturbance during the Early Holocene.}

The time interval between 8400 and 7900 cal BP is well known as a colder and more humid specific period through the North Atlantic regions and the Alps (von Granfenstein et al., 1999). This climatic change involved an increase in regional humidity in Western Europe (Magny et al., 2001) and modified the upper vegetation cover in the Alpine region (Haas et al, 1998). It seems that the " 8200 cal BP climatic deterioration" identified by von Granfenstein et al., (1999) in the Northern Alps foreland also slightly influenced the vegetation cover of the 
drainage-basin of Lake Paladru since higher values of the rAP/LCF ratio are recorded (Figure 4F). It also favoured a weak increase of soil erosion (Figure 4C) in the drainage basin of Lake Paladru which induced higher algal production (Figure 4A). Similar trends and processes are described during this period by Hede et al. (2010) in Northern Europe.

\subsection{0-5500 and 5200-4800 cal BP: various disturbances during the Neoglacial transition.}

From 6000 to $4800 \mathrm{cal} \mathrm{BP}$, algal production as well as soil particles and upper vegetation debris contributions increased at site PAL09 (Figures 4A, 4C, 4D). This could result from the transition to a more humid climate which did not influence the vegetal covered but enhanced inwash of soil nutrients, favouring algal productivity. This increase in soil erosion could in particular result from the higher runoff documented at the onset of the Neoglacial period (Wanner et al., 2011), characterized in the Alps by changes in moisture conditions (Haas et al., 1998). In agreement with paleoenvironmental reconstructions from Bocquet and Noël (1995), the rAP/LCF ratio indicates that the catchment of Lake Paladru was forested and not affected by landscape disturbances (Figure 4F). At the regional scale, and more specifically in the Rhône valley floodplains, at Lake Le Bourget and at the Bourgoin swamp (Figure 1), Late Neolithic sites are in addition documented (Marguet et al., 2008, Berger, 2007a, Gauthier and Richard, 2009, Bernigaud, 2012). Human settlements and woodland exploitation were also firmly established by $4950 \mathrm{cal}$ BP on the southern shore of Lake Paladru (Figures 1 and 4, Bocquet and Noël, 1995), suggesting that human activities could impact their environments in this part of the Prealps. Such practices may have induced disturbances within a catchment and could have contributed to the higher erosion of soil particles detected in core PAL09. However, since no significant landscape disturbance has been detected by the rAP/LCF ratio (Figure 4F), it is very likely that Neolithic woodland exploitation were restricted to the vicinity of the villages notably located close to the lake outlet. It suggests that lacustrine sedimentation at site PAL09 is mainly sensitive to environmental changes upstream from its tributaries (i.e. the northern parts of the drainagebasin). This further indicates that around Lake Paladru, the Late Neolithic period was more driven by progressive regional hydrological changes (Magny, 2004; Arnaud et al., 2005; Chapron et al, 2005) rather than human influences. 


\subsection{0-3200 cal BP: Bronze Age agrarian activities and associated consequences.}

A phase of progressive watershed disturbance and higher soil fluxes started in 4300 cal BP and reached its maximum in $3300 \mathrm{cal} \mathrm{BP}$ (Figures 4F and 4C). This time interval is documented as being a period of warmer and drier climate marked by two phases of reduced glacial activity in the Western French Alps (Guyard et al., 2007) allowing the development of high-altitude upper vegetation (Carozza et al., 2010). Such climatic conditions could not explain the progressive increase of soil particles erosion (Figure 4C and increase in rAP/LCF ratio, Figure 4F) suggesting enhanced runoff processes and a wetter climate. During the same time lapse, Alpine human occupations are well documented through the Rhone valley nearby Lake Paladru (Figure 1, Berger et al., 2007b; Bernigaud, 2012) but only suggested by Brochier et al. (2007) around Lake Paladru. The first occurrence of miliacin in the sedimentary infill of Lake Paladru is however detected and dated in $3500 \mathrm{cal} \mathrm{BP}$ (Figure 4G) and reached its highest concentration in 3200 cal BP. Miliacin occurrence in Lake Paladru is thus almost synchronous (i) with the beginning of the millet cultivation around Lake Le Bourget in 3700 cal BP (Figure 1, Jacob et al., 2008) and (ii) with the extensions of agricultural territories and the development of sites with storage structures in the region during the second half of the Early Bronze Age (Berger et al., 2007b). It suggests that despite the absence of clear archaeological evidence of lake-dwelling along littoral environments, agrarian activities were developed within the drainage-basin of Lake Paladru during the Bronze Age period. The progressive increase of the ratio rAP/LCF since $4500 \mathrm{cal}$ BP seems therefore to correspond both to the expansion of landscape opening for cereals cultivation and to the first rise of human-induced soil erosion.

The abrupt decrease in miliacin concentration in 3100 cal BP at site PAL09 is synchronous with the decrease of the ratio rAP/LCF (Figure 4F) reflecting the drop in soil particles erosion (Figure 4C). This abrupt stop coincided with the quasi absence of human activities in littoral environments of Lake Paladru (Brochier et al., 2007) and with regional abandonment of farmland during the Late Bronze Age period (Berger et al., 2007b).

Furthermore, this time-interval is marked by regional colder and more humid periods in the French Alps (Arnaud et al., 2005; Chapron et al, 2005; Guyard et al., 2007; Debret et al., 2010). The synchronicity between the lowering of human impacts at Lake Paladru and the climatic pejoration thus supports the interpretations of Magny (2004) and Jacob et al. (2008) that regional climate-related cultural changes favoured the abandonment of lake-dwellings sites in Prealps during the Late Bronze Age. 


\subsection{0-2050 cal BP: Iron Age agrarian activities and drastic soil erosion.}

The 2700-2050 cal BP time interval is a second phase of watershed disturbance (Figure 4F) associated with millet cultivation (Figure 4G). As previously, this period is synchronous with the nearby Lake Le Bourget sedimentary record (Jacob et al., 2008), confirming a regional agrarian pattern in the French Prealps, itself synchronous with regional anthropogenic pressures (Berger et al., 2007b). This period of higher soil erosion (Figure 4C) is in addition marked by the occurrence of first traces of titanium at PAL09 coring site (Figure $4 \mathrm{H})$. The simultaneous presence of organic and minerogenic pedological markers seems to indicate that until $2700 \mathrm{cal} \mathrm{BP}$, soil disturbance was not enough intense to generate physical weathering. During the Iron Age (Hallstatt and La Tene periods), soil organic fluxes were indeed two times superior to the ones recorded during the first phase of millet cultivation (Figure 4C). It could indicate the intensification of both soil erosion and human land-use. It seems thus very likely that the first phase of exploitation, in the Mid-Late Bronze Age, only affected the superficial soil layers rich in organic fraction (rAP), while during the Iron Age, soil erosion in similar areas (or different land-use) have reached deeper layers richer in the mineral fraction. The convergence of ploughing practices intensification and of a global climatic degradation (van Geel and Rensen 1996) could thus explain this abrupt change in soil erosion process.

After 2050 cal BP, miliacine content in lacustrine sediments were not analysed, but lower soil erosion and lower rAP/LCF ratio are recorded within the sediment until $1600 \mathrm{cal}$ $\mathrm{BP}$ (Figures 4C, 4F and 4F) and contrast with the higher titanium supply (Figure 4H). If some peaks of titanium could be related to flood events induced by heavy rainfalls or storm events, enhanced titanium supply at site PAL09 can hardly be explained by wetter climate, since the time interval 2050-1600 cal BP corresponds to a sharp drop in lake-level in the Alpine region (Magny, 2004). The minerogenic supply during this period could therefore essentially result from the progressive destabilization of soil deeper layers initiated during the Iron Age in the drainage basin. It suggests an evolution of human land-use to intensive disturbances, such as deeper ploughing, which could remobilize deeper soil layers richer in minerogenic compounds and explain the diminution of the soil organic matter supply (Figure 4C). This interpretation is in agreement with Berger et al. (2007a) who documented both humaninduced extensive weakening of the soil systems and increasing minerogenic suspension load 
in the fluvial systems of the Rhone watershed, between 2050 and $1850 \mathrm{cal} \mathrm{BP}$ at the regional scale. In addition, the dilution of soil organic nutrients loading by minerogenic inputs induced a lowering of the algal production in Lake Paladru during this period (Figure 4A). .

\subsection{0-1100 cal BP (AD350-850): Early Medieval human-induced soil erosion.}

Between AD350 and AD850, core PAL09 recorded both enhanced organic and minerogenic pedological supply (Figures 4C, 4H) which increased the rAP/LCF ratio (Figure 4F). This period matches well-documented human activities within the Prealps (Noël et al., 2001; Berger et al., 2007a) and notably within the catchment of Lake Paladru where Brochier et al. (2007) and Borel et al. (1994) described enhanced detritism phases and land openness interpreted as resulting from the development of medieval human communities. Indeed, the new increase in soil organic supply suggests an extension of human land-use and soil erosion to previously preserved territories. Such new landscape instabilities induced drastic modifications in Lake Paladru trophic levels since the algae production was multiplied by more than three (Figure 4B). This phase correspond with a very high detritic period associated with a plurisecular Rhone river floods increase in the Lake Le Bourget (Chapron et al, 2005; Arnaud et al. 2005; Debret et al, 2010) and with a torrential activity of the Rhone river and its tributaries in the upper Rhone valley.

\subsection{0 cal BP (AD1000) in Lake Paladru}

Between AD850-1200, lower soil supply and associated algal productivity are recorded in core PAL09 (Figures 4C, 4H, 4A) suggesting a relative stability of the landscape, in agreement with a regional pattern documented by Berger et al. (2007a) between AD9001300/1500. Borel et al. (1994) and Brochier et al. (2007) largely documented a period of lower lake-level allowing the development of lake-dwellings at AD1000 (Figure 1) along the littoral environments of Lake Paladru. This drier period suggests lower runoff process and could therefore explain the lower terrestrial fluxes recorded at core PAL09. Intensive humaninduced soil destabilizations within the drainage basin were however described between AD1000-1040 (Borel et al., 1994; Brochier et al., 2007) and identified as the cause of the abrupt end of the Colletière village, in AD1040 (Brochier and Druart, 1993). If no higher organic terrestrial supply are detected in core PAL09, the increasing contribution of titanium 
around AD1000 (Figure 4H) could attest of the cumulative effects of human-induced deep soil destabilization around Lake Paladru and an increase of runoff processes due to large-scale climate deterioration phases documented in the Alps by Wanner et al. (2011). This interpretation is in agreement with the conclusions from Brochier et al. (2007) who suggested that both climate and human activities during this period could have affected the geomorphology of the lake outlet and induced a rapid rise of Lake Paladru level leading to the desertion of the Colletière village.

\subsection{AD1250-1850: Little Ice Age and historical human imprints in Lake Paladru sediments}

After AD1250, organic and minerogenic terrestrial markers increased (Figures 4C, 4F, 4H) suggesting a new phase of enhanced soil erosion favouring algal productivity (Figure 4A). This significant environmental change could result both from (i) a regional imprint of a wetter and colder climate during the Little Ice Age (Chapron et al, 2002, 2007; Magny et al., 2011; Wanner et al. 2011) which probably contributed to the increase in soil erosion, and (ii) significant human pressures in the catchment area of Lake Paladru. According to Colardelle and Verdel (1993), the historical ecclesiastical activities within Lake Paladru watershed have consisted of intensive disturbances resulting from the development of agriculture and fish breeding in artificial reservoir lakes (Figure 1). It seems therefore that such activities deeply affected the vegetation cover and favoured enhanced terrestrial fluxes to the lake.

\subsection{Post AD 1850: Modern human-induced disturbances.}

Algal production in Lake Paladru became maximal during the Modern time after AD1970 (Figure 4A).These modern drastic environmental changes confirm that human activities and in particular modern agriculture practices are not limited to erosion processes but also deeply affected the trophic state of Lake Paladru (Touchart, 1993).

\section{Conclusions}

Past interactions between human land-use and climate fluctuations in Lake Paladru are documented using the minerogenic and organic signals of lacustrine sediment with 
archaeological data. The study of the sedimentary organic matter allows in particular discriminating, identifying and quantifying organic components originating from the autochthonous production from those derived from runoff processes on soils. During the Early-Mid Holocene (10000-5200 cal BP), lacustrine sediment was essentially made of algae and autochthonous carbonates and the catchment was largely forested. The abrupt climatic event from $8200 \mathrm{cal}$ BP induced a decrease of the upper vegetation cover and higher soil erosion reflecting an abrupt colder and more humid episode. After $5200 \mathrm{cal} \mathrm{BP}$, the enhanced soil erosion resulted of climatic deterioration phases typical of the Neoglacial period, and/or higher human pressures within the watershed of Lake Paladru already documented by archaeologists or historical writings during the Late Neolithic, the Middle Age and the Modern period. Previously unknown phases of human activities are identified during the Bronze, the Iron and the Roman periods. Each of them was associated with enhanced soil weathering characterized by higher terrestrial organic and minerogenic supply, resulting from human-induced land openness and/or deep soil destabilization induced by modification of human land-use. Molecular markers, such as the miliacin, brought further information about past regional agrarian practices and agricultural dynamics through the Prealps, in particular considering the broomcorn millet. It particularly attests of the human presence around Lake Paladru during the Bronze Age and the Iron Age and suggests that during these two periods, human did not live on littoral sites but more within the watershed.

\section{Acknowledgements}

We acknowledge the financial support of the ANR Pygmalion and the ANR PalHydroMil. We thank ISTO members (Disnar JR, Jacob J, Le Milbeau C, Boscardin R, Hatton M), Gratuze B (IRAMAT Orléans) and Garcia M (CEREGE, Aix-en-Provence) for their valuable advices during analyses. Ledoux G., Fanget B, Graz Y, Mallet E and Stock A. are also acknowledged for their help during field work campaigns. The Artemis radiocarbon committee (INSU/CNRS) and the Saclay team are thanked for radiocarbon dating. A. Simonneau benefits from a PhD grant provided by the Region Centre. We would also like to warmly thank Verdel E. for logistical support and fruitful scientific discussions on human activities near Lake Paladru, and Lovato M. as well as Matheron G. for their contributions to maintain and protect Lake Paladru. We also thank the editor and two anonymous reviewers for their comments and suggestions that improved the manuscript. 


\section{References}

Anspaugh, L.R., Catlin, R.J., Goldman, M., 1988. The Global Impact of the Chernobyl Reactor Accident. Science. 242, 1513-1519.

Appleby, P.G., Oldfield, F., 1978. The calculation of lead-210 dates assuming a constant rate of supply of unsupported ${ }^{210} \mathrm{~Pb}$ to the sediment. Catena. $5,1-8$.

Ariztegui, D., Anselmetti, F.S., Robbiani, J.M., Bernasconi, S.M., Brati, E., Gili, A., Lehmann, M.F., 2010. Natural and human-induced environmental change in southern Albania for the last 300 years - Constraints from the Lake Butrint sedimentary record. Global and planetary Change. 71, 183-192.

Arnaud, F., Revel, M., Chapron, E., Desmet, M., Tribovillard, N., 2005. 7200 years of Rhone river flooding activity in Lake Le Bourget, France: a high-resolution sediment record of NW Alps hydrology. The Holocene. 15, 420-428.

Arnaud, F., Révillon, S., Debret, M., Revel, M., Chapron, E., Jacob, J., Giguet-Covex, C., Poulenard, J., Magny, M., 2012. Lake Bourget regional erosion patterns reconstruction reveals Holocene NW European Alps soil evolution and paleohydrology. Quaternary Science Review, 51, 81-92.

Beck, H.L., Helfer, I.K., Bouville, A., Dreicer, M., 1990. Estimated of fallout in the continental U.S. from Nevada weapons testing based on gummed-film monitoring data. Health Physics. 59, 565-576.

Berger, J.F., Nuninger, L., van der Leeuw, S.E., 2007a. Modeling the Role of Resilience in Socioenvironmental Co-evolution The Middle Rhône Valley between 1000BC and AD1000. in: The Model-Based Archaeology of Scionatural Systems, Kohler TA, van der Leeuw SE (Eds.), School for Advanced Research Press, Santa Fe, pp. 41-59.

Berger, J.F., Brochier, J.L., Vital, J., Delhon, C., Thiébault, S., 2007b. Nouveau regard sur la dynamique des paysages et l'occupation humaine à l'Âge du Bronze en moyenne vallée du Rhône. in : Environnements et cultures à l'âge du Bronze en Europe occidentale Actes du 129e colloque du CTHS, Besançon, avril 2004, Mordant C, Richard H, Magny M (Eds), pp. 260-283. 
Bernigaud, N., 2012. Evolution des anthroposystèmes des marais de Bourgoin-la-Verpillière (Isère) du Néolithique final à l'Antiquité tardive (3000BC-AD600) : archéologie du paysage et de l'environnement. Thèse de doctorat de l'Université de Nice.

Blaauw, M., 2010. Methods and code for 'classical' age-modelling of radiocarbon sequences. Quaternary Geochronology. 5, 512-518.

Bocquet, A., Noël M., 1995. The Neolithic or Wood Age. Endeavour New Series. 9, 34-41.

Borel, J.L., Brochier, J.L., Druart, J.C., 1994. Microlaminations lacustres : variations bathymétriques et climatiques avant l'An mil sur le site de Colletière, Lac de Paladru, France. Quaternaire. 5, 105-111.

Bosco, C., Rusco, E., Montanarella, L., Panagos, P., 2009. Soil erosion in the Alpine area: risk assessment and climate change. Studi Trent. Sci. Nat. 85, 117-123.

Bouby, L., Billaud, Y., 2001. Economie agraire à la fin de l'âge du Bronze sur les bords du lac du Bourget (Savoie, France). Compte Rendu de l'Académie des Sciences. II A 333, 749756.

Bravard, C., Gidon, M., Steinfatt, E., Gravelot, R., 1970. Carte géologique détaillée de la France au 1/50000, Voiron, $n^{\circ} 748$.

Brochier, J.L., Druart, J.C., 1993. Le milieu lacustre. in: Les habitats du lac Paladru (Isère) dans leur environnement. La formation d'un terroir au Xle siècle, Colardelle M, Verdel E. (Eds), Doc. Archéol. française, MSH, Pans, 40, pp. 39-61.

Brochier, J.L., Borel, J.L., Druart, J.C., 2007. Les variations paléoenvironnementales de 1000 avant à 1000 après J.C. et la question des « optima » climatiques de l'Antiquité tardive et du Moyen-âge sur le piedmont des Alpes du nord à Colletière, Lac de Paladru, France.

Quaternaire. 18, 253-270.

Carozza, L., Chapron, E., Simonneau, A., Mille, B., Guyard, H., St-Onge, G., Rostan, P., Bourgarit, D., Burens A., 2010. Glacial fluctuations and exploitation of copper resources in high moutain during the Late Neolithic and Bronze Age in the French Alps (2500-1500 BC). Mining in European History and its impact on environment and human societies, in: Proceedings for the $1^{\text {st }}$ Mining in European History-Conference of the SFB-HIMAT, 12-15. November 2009, Innsburck, Austria, pp. 81-88. 
Cerdà, A., 1998. The influence of geomorphological position and vegetation cover on the erosional and hydrological processes on a Mediterranean hillslope. Hydrological Processes. $12,661-671$.

Chapron, E., Desmet, M., De Putter, T., Loutre, M.F., Beck, C., Deconinck, J.F., 2002.

Climatic variatbility in the northwestern Alps, France, as evidence by 600 years of terrigenous sedimentation in Lake Le Bourget, The Holocene. 12, 177-185.

Chapron, E., Arnaud, F., Noel, H., Revel, M., Desmet, M., Perdereau, L., 2005. Rhone river flood deposits in Lake Le Bourget: a proxy for Holocene environmental changes in the NW Alps, France. Boreas. 34, 404-416.

Chapron, E., Faïn, X., Magnad, O., Charlet, L., Debret, M., Mélières, M.A., 2007.

Reconstructing recent environmental changes from proglacial lake sediments in the Western Alps (Lake Blanc Huez, 2543 m a.s.l. Grandes Rousses Massif, France). Palaeogeography, Palaeoclimatology, Palaeoecology. 252, 586-600.

Colardelle, M., Verdel, E., 1993. Les habitats du lac de Paladru (Isère) dans leur environnement. La formation d'un terroir au Xle siècle. Doc. Archéol. Française. 40.

Croudace, I.W., Rindby, A., Rothwell, R.G., 2006. ITRAX: description and evaluation of a new multi-function X-ray core scanner. in: New Techniques in Sediment Core Analysis. Geol. Soc. Spec. Publ., Rothwell, R.G. (Eds.), London, pp. 51-63.

Dearing, J.A., 2006. Climate-human-environment interactions: resolving our past. Climate of the Past. 2, 187-2003.

Debret, M., Chapron, E., Desmet, M., Rolland-Revel, M., Magand, O., Trentesaux, A., BoutRoumazeille, V., Nomade, J., Arnaud, F., 2010. North western Alps Holocene paleohydrology recorded by flooding activity in Lake Le Bourget, France. Quaternary Science Reviews. 29, 2185-2200.

Di Giovanni, C., Disnar, J.R., Campy, M., Bichet, V., Guillet, B., 1998. Geochemical characterization of soil organic matter and variability of a post glacial detrital organic supply (Chaillexon lake, France). Earth Surface Processes and Landforms. 23, 1057-1069. 
Di Giovanni, C., Disnar, J.R., Bichet, V., Campy, M., 2000. Seasonal variability and threshold effects of the organic detrital sedimentation in lakes: imbalances between organic records and climatic fluctuations (Chaillexon basin, Doubs, France). Bulletin de la Société géologique de France. 171, 533-544.

Duchaufour, P., 1983. Pédogenèse et classification $2^{\mathrm{e}}$ édition. Masson (Eds), Paris.

Gauthier, E. and Richard, H., 2009. Bronze Age at Lake Bourget (NW Alps, France): Vegetation, human impact and climatic change. Quaternary International. 200, 111-119.

Graz, Y., Di Giovanni, C., Copard, Y., Laggoun-Défarge, F., Boussafir, M., Lallier-Vergès, E., Baillif, P., Perdereau, L., Simonneau, A., 2010. Quantitative palynofacies analysis as a new tool to study transfers of fossil organic matter in recent terrestrial environments. International Journal of Coal Geology. 84, 49-62.

Guiguet-Covex, C., Arnaud, F., Poulenard, J., Disnar, J.R., Delhon, C., Francus, P., David, F., Enters, D., Rey, P.J., Delannoy, J.J., 2011. Changes in erosion patterns during the Holocene in a currently treeless subalpine catchment inferred from lake sediment geochemistry (Lake Anterne, 2063 m a.s.l., NW French Alps): The role of climate and human activities. The Holocene. 21, 651-665.

Guyard, H., Chapron, E., Saint-Onge, G., Anselmetti, F.S., Arnaud, F., Magand, O., 2007. High-altitude varves records of abrupt environmental changes and mining activity over the last 4000 years in the Western French Alps (Lake Bramant, Grandes Rousses massif). Quaternary Science Reviews. 26, 2644-2660.

Haas, J.N., Richoz, I., Tinner, W., Wick, L., 1998. Synchronous Holocene climatic oscillations recorded on the Swiss Plateau and at timberline in the Alps. The Holocene. 8, 301-309.

Hede, M.U., Rasmussen, P., Noe-Nygaard, N., Clarke, A.L., Vinebrooke, R.D., Olsen, J., 2010. Multiproxy evidence for terrestrial and aquatic ecosystem responses during the $8.2 \mathrm{ka}$ cold event as recorded at Højby Sø, Denmark. Quaternary Research. 73, 485-496.

Hurtt, G.C., Frolking, S., Fearon, M.G., Moore, B., Shevliakova, E., Malyshev, S., Pacala, S.W., Houghton, R.A., 2006. The underpinnings of land-use history: three centuries of global gridded land-use transitions, wood-harvest activity, and resulting secondary lands. Global Change Biology. 12, 1208-1229. 
Jacob, J., Disnar, J.R., Arnaud, F., Chapron, E., Debret, M., Lallier-Vergès, E., Desmet, M., Revel-Rolland, M., 2008. Millet cultivation history in the French Alps as evidence by a sedimentary molecule. Journal of Archaeological Science. 35, 814-820.

Jacob, J., Disnar, J.R., Arnaud, F., Gauthier, E., Billaud, Y., Chapron, E., Bardoux, G.. 2009. Impacts of new agricultural practices on soil erosion during the Bronze Age in the French Prealps. The Holocene. 19, 241-249.

Le Bissonnais, Y., Montier, C., Jamagne, M., Daroussin, J., King, D., 2001. Mapping erosion risk for cultivated soil in France. Catena. 46, 207-220.

Magny, M., Marguet, A., Chassepot, G., Richard, H., Billaud, Y., 2001. Early and late Holocene water-level fluctuations of Lake Annecy, France: sediment and pollen evidence and climatic implications. Journal of Palaeolimnology. 25, 215-227.

Magny, M., 2004. Holocene climate variability as reflected by mid-European lake-level fluctuations and its probable impact on prehistoric human settlements. Quaternary International. 113, 65-79.

Magny, M., Peyron, O., Gauthier, E., Vannière, B., Millet, L., Vermot-Desroches, B., 2011. Quantitative estimates of temperature and precipitation changes over the last millenium from pollen and lake-level data at Lake Joux, Swiss Jura Mountains. Quaternary Research. 75, 4554.

Marguet, A., Bintz, P., Nicod, P.Y., Picavet, R., Rey, P.J., Thirault, E., 2008. Element for a settlement history of North French Alps between 10000 and 2700 years BP. in: Cahier de Paléoenvironnement, Collection Edytem n ${ }^{\circ}$, pp. 225-252.

Massa, C., Bichet, V., Gauthier, E., Perren, B.B., Mathieu, O., Petit, C., Monna, F., Giraudeau, J., Losno, R., Richard, H., 2012. A 2500 year record of natural and anthropogenic soil erosion in South Greenland. Quaternary Science Reviews. 32, 1193-130.

Millet, L., Vannière, B., Verneaux, V., Magny, M., Disnar, J.R., Laggoun-Défarge, F., Walter-Simonnet, A.V., Bossuet, G., Ortu, E., de Beaulieu, J.L., 2007. Response of littoral chironomid communities and organic matter to late glacial lake-level, vegetation and 
climate changes at Lago dell'Accesa (Tuscany, Italy). Journal of Paleolimnology. 38, 525539.

Noël, H., Garbolino, E., Brauer, A., Lallier-Vergès, E., de Beaulieu, J.L., Disnar, J.R., 2001. Human impact and soil erosion during the last $5000 \mathrm{yrs}$ as recored in lacustrine sedimentary organic matte rat Lac d'Annecy, the French Alps. Journal of Paleolimnology. 25, 229-244.

Patience, A.J., Lallier-Vergès, E., Sifeddine, A., Albéric, P., Guillet, B., 1995. Organic fluxes and early diagenesis in the lacustrine environment. in: Organic matter accumulation. LallierVergès, E., Tribovillard, N., Bertrand, P. (Eds), Lecture Notes in Earth Sciences, Springer, Heidelberg, 57, pp.145-156.

Ramanampisoa, L., Disnar, J.R., 1994. Primary control of paleoproduction on organic matter preservation and accumulation in the Kimmeridge rocks of Yorkshire (UK). Organic Geochemistry. 21, 1153-1167.

Reimer, P.J., Baillie, M.G.L., Bard, E., Bayliss, A., Beck, J.W., Blackwell, P.G., Bronk Ramsey, C., Buck, C.E., Burr, G.S., Edwards, R.L., Friedrich, M., Grootes, P.M., Guilderson, T.P., Hajdas, I., Heaton, T.J., Hogg, A.G., Hughen, K.A., Kaiser, K.F., Kromer, B., McCormac, F.G., Manning, S.W., Reimer, R.W., Richards, D.A., Southon, J.R., Talamo, S., Turney, C.S.M., van der Plicht, J., Weyhenmeyer, C.E., 2009. IntCal09 and Marine09 radiocarbon age calibration curves, 0-50,000 years cal BP. Radiocarbon. 51, 1111-1150.

Reynolds, C., Dokulil, M., Padisák, J., 2000. Understanding the assembly of phytoplankton in relation to the trophic spectrum: where are we now? Hydrobiologia. 424, 147-152.

Sebag, D., Copard, Y., Di Giovanni, C., Durand, A., Laignel, B., Ogier, S., Lallier-Vergès, E., 2006. Palynofacies as useful tool to stydy origins and trandfers of particulate organic matter in recent terrestrial environments: Synopsis and prospects. Earth-Science Reviews. 79, 241-259.

Talbot, M.R., Livingstone, D.A., 1989. Hydrogen index and carbon isotopes of lacustrine organic matter as lake level indicators. alaeogeography, Palaeoclimatology, Palaeoecology. 70, 121-137.

Tinner, W., Lotter, A.F., Ammann, B., Conedera, M., Hubschmid, P., van Leeuwen, J.F.N., Wehrli, M., 2003. Climatic change and contemporaneous land-use phases north and south of the Alps 2300 BC to 800 AD. Quaternary Science Reviews. 22, 1447-1460. 
Touchart, L., 1993. La machine lacustre: l'exemple du Léman. Annales de Géographie. 573, 449-471.

Tyson, R.V., 1995. Sedimentary Organic Matter: Organic Facies and Palynofacies. Chapman \& Hall (Eds), London.

Van Geel, B., and Renssen, H., 1996. Archaeological and palaeocological indications of an abrupt climatic change in the Netherland and evidence for climatological teleconnections around 2650 BP. Journal of Quaternary Science. 11, 451-460.

von Granfenstein, U., Erlenkeuser, H., Brauer, A., Jouzel, J., Johnsen, S., 1999. A MidEuropean Decadal Isotope-Climate Record from 15,500 to 5000 Years B.P. Science. 284, 1654-1657.

Wanner, H., Solomina, O., Grosjean, M., Ritz, S.P., Jetel, M., 2011. Structure and origin of Holocene cold events. Quaternary Science Reviews. 30, 3109-3123.

Weliky, K., Suess, E., Ungerer, C.A., 1983. Problems with accurate carbon measurements in marine sediments and particulate matter in seawater: A new approach. Limnology and Oceanography. 28, 1252-1259. 


\section{Figure captions}

\section{Figure 1}

General localisation and geomorphological setting of Lake Paladru in the western French Prealps (left upper panel). Numerous archaeological sites (white starts) are documented by subaquatic archaeological surveys on the lake shore. The location of the longitudinal seismic profile (P1, lower panel) is given on the bathymetric map. Core PAL09 was taken in the central basin in an area free from any mass wasting deposits (MWD) remoulding the basin fill and preventing the penetration of the acoustic signal. The five first upper meters of core PAL09 presented in this study allow calibrating four different seismic units (SU1 to SU4).

\section{Figure 2}

The Master core PAL09 (A) is divided into 5 sedimentary units (from U1 to U5, from base to top) defined by variations of the magnetic susceptibility and calcium carbonate or total organic carbon (TOC) contents. Calcium carbonate amounts are calculated from the inorganic carbon measurements. The age depth model of core PAL09 (B) is supported by radiometric measurements (window) and by 15 radiocarbon ages (white leaves) detailed in Table 1.

\section{Figure 3}

Rock-Eval pyrolysis results (A) are represented on a S2 (mg HC) versus Total Organic Carbon (TOC, \%) diagram for soil (black squares), river-beds (grey triangles) and lacustrine (white diamonds) samples. Black full lines 750 and $300 \mathrm{mgHC} . \mathrm{g}^{-1} \mathrm{TOC}$ represent the aquatic and the terrestrial domains, respectively. The main components of the organic fraction identified and quantified by quantitative organic petrography are presented (B). Red Amorphous Particles (rAP) and ligno-cellulosic fragments (LCF) are found in soil, river-beds and lacustrine samples whereas grey Amorphous Particles (gAP) are only found in lacustrine samples.

\section{Figure 4}

Synthetic presentation of Lake Paladru data collected at core PAL09. The algal content quantified by quantitative organic petrography (A) is compared to the hydrogen index (HI) delivered by Rock-Eval pyrolysis (B), the soil particles (rAP) content quantified by quantitative organic petrography (C), the ligno-cellulosic debris (LCF) amount quantified by quantitative organic petrography (D), the accumulation rate expressed in $\mathrm{cm} \mathrm{yr}^{-1}(\mathrm{E})$, the ratio 
rAP/LCF (F), the occurrence of miliacin molecular biomarker in Lake Paladru sediments (the black arrow symbolised the first occurrence of miliacine in Lake Le Bourget sediments, from Jacob et al., 2008) (G) and the titanium content $(\mathrm{H})$ measured by XRF core scanning.

\section{Table 1}

Radiocarbon dates obtained from Lake Paladru sediment sequence PAL09. Age calibration was done using sets by Reimer et al. (2009). The two dates in italic are the rejected dates (see the text for more details). 
1 Table 1

\begin{tabular}{|c|c|c|c|c|c|}
\hline Method & Material & Laboratory & Depths (cm) & Radiocarbon ages & Calibrated ages (cal. yr BP) \\
\hline \multirow{16}{*}{ AMS ${ }^{14} \mathrm{C}$} & Wood & Poz-37099 & 60 & $750 \pm 60$ & $712 \pm 78$ \\
\hline & Wood & Poz-37096 & 99 & $1250 \pm 30$ & $1220 \pm 54$ \\
\hline & Vegetal & SacA 20695 & 101 & $1245 \pm 30$ & $1192 \pm 75$ \\
\hline & Wood & SacA 20696 & 126 & $1525 \pm 25$ & $1385 \pm 37$ \\
\hline & Wood & Poz-37098 & 161.5 & $2220 \pm 60$ & $2228 \pm 119$ \\
\hline & Wood & SacA 20699 & 191 & $2670 \pm 30$ & $2773 \pm 26$ \\
\hline & Wood & SacA 20697 & 231 & $3410 \pm 30$ & $3648 \pm 73$ \\
\hline & Wood & Poz-37094 & 261 & $4210 \pm 40$ & $4692 \pm 73$ \\
\hline & Vegetal & SacA 20701 & 266 & $4270 \pm 35$ & $4846 \pm 34$ \\
\hline & Wood & SacA 20700 & 301 & $5055 \pm 30$ & $5818 \pm 83$ \\
\hline & Wood & Poz-37093 & 331 & $6650 \pm 80$ & $7528 \pm 100$ \\
\hline & Wood & Poz-37095 & 395 & $8670 \pm 50$ & $9652 \pm 116$ \\
\hline & Wood & Poz-37100 & 429 & $9880 \pm 90$ & $12576 \pm 63$ \\
\hline & Vegetal & SacA 20694 & 429 & $10590 \pm 45$ & $11407 \pm 244$ \\
\hline & Wood & Poz-37092 & 481 & $12470 \pm 80$ & $14601 \pm 446$ \\
\hline & Vegetal & SacA 20698 & 510.5 & $12020 \pm 50$ & $13881 \pm 131$ \\
\hline
\end{tabular}

2 

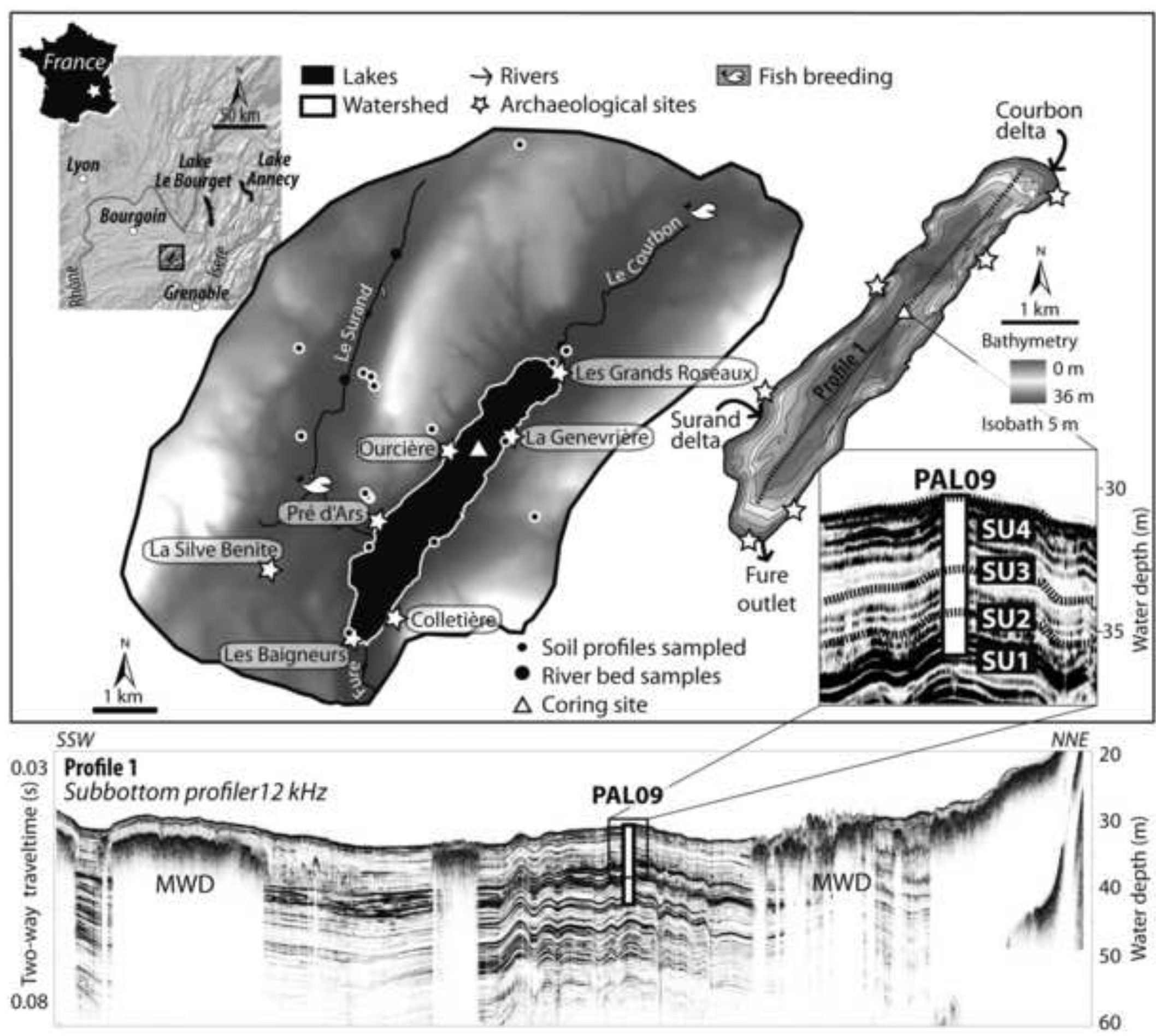
(A) Core PALO9

Magnetic Susceptibility

TOC (\%)

cal BP

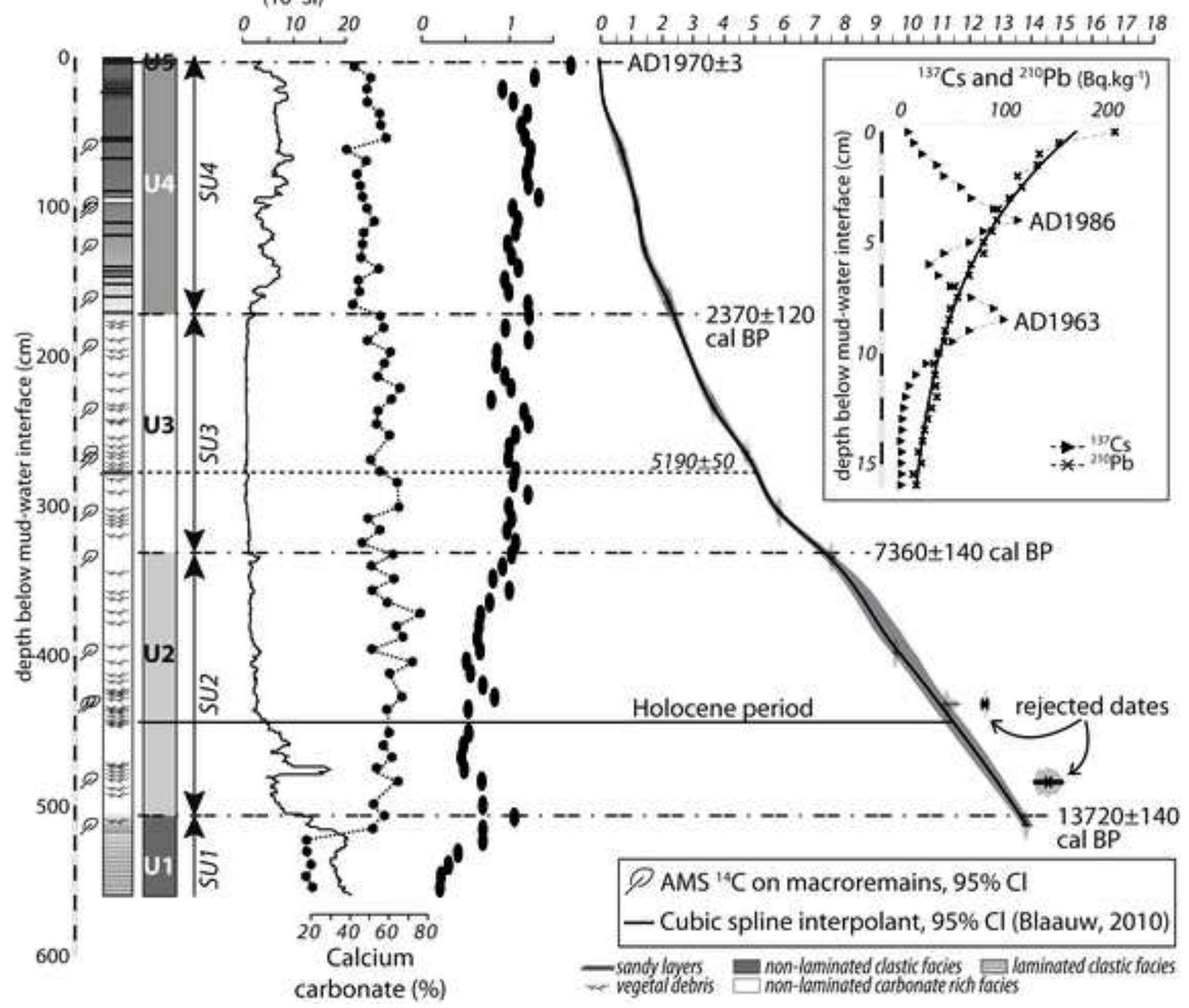



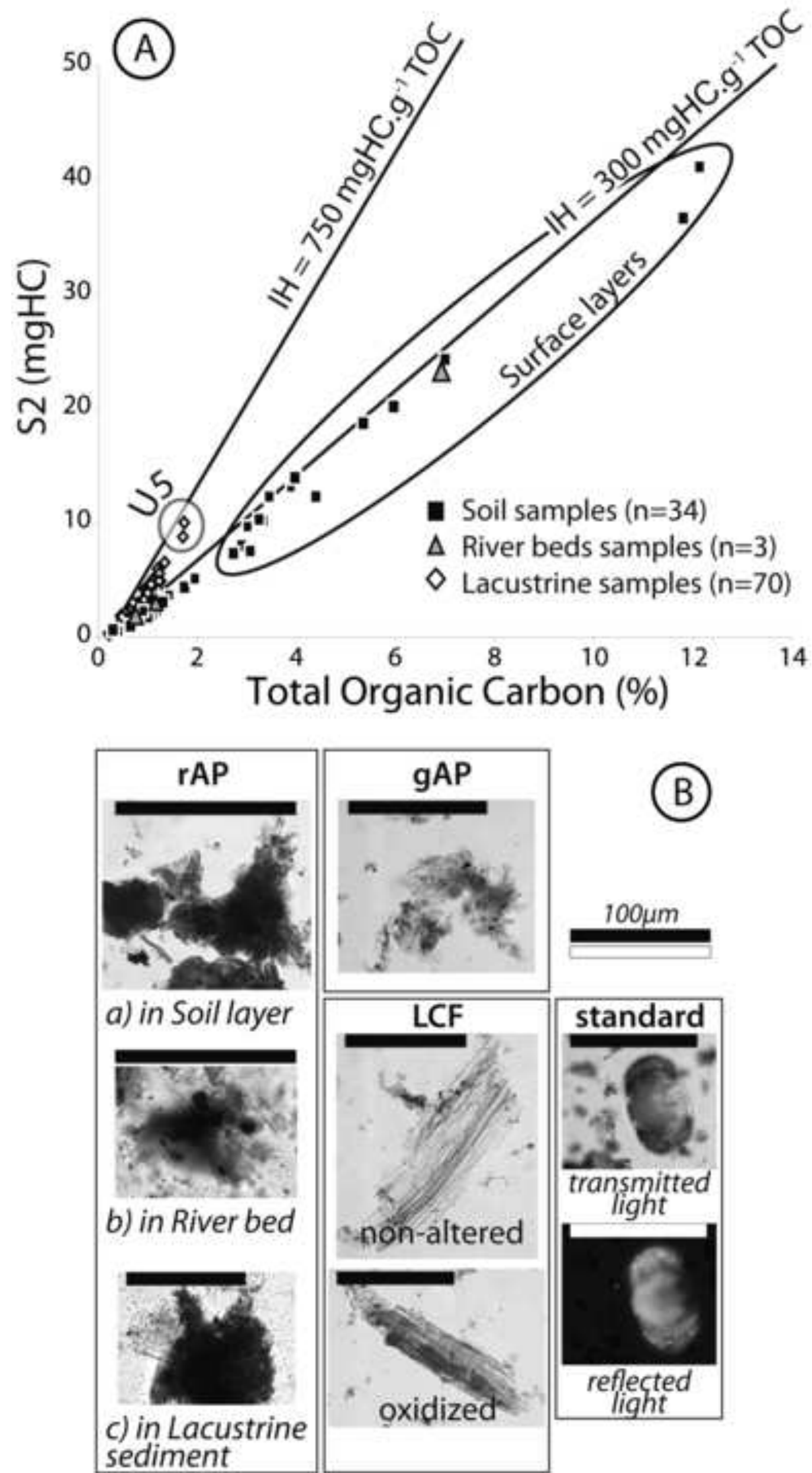
